\title{
WHAT FUNDAMENTALLY DRIVES GROWTH? REVISITING THE INSTITUTIONS AND ECONOMIC PERFORMANCE DEBATE
}

\author{
JESSICA HENSON DECKER ${ }^{1}$ and JAMUS JEROME LIM ${ }^{2 *}$ \\ ${ }^{1}$ Centre College, Danville, USA \\ ${ }^{2}$ World Bank, Washington, USA, and SCCIE, Santa Cruz, USA
}

\begin{abstract}
The recent empirical growth literature has proposed three underlying fundamental determinants of economic growth, namely, physical geography, economic integration and institutional quality. This paper unpacks the final determinant into both political-economic institutions as well as the primarily political institution of democratic development. Using both cross-sectional and panel datasets, we show that, properly instrumented, there is no evidence that democracies grow faster or slower than non-democracies. This result is in contrast to much of the more recent literature, which tends to find a weakly positive relationship. Politicaleconomic institutions, however, remain positive and significant determinants of economic growth, which corroborates much of the empirical evidence in the existing literature. Copyright (C) 2008 John Wiley \& Sons, Ltd.
\end{abstract}

Keywords: economic growth; institutions; democracy

JEL classification numbers: O17, O57, P51

\section{INTRODUCTION}

The recent literature on the underlying 'fundamental' determinants ${ }^{1}$ of economic growth has developed around three main strands: the influence of physical geography, primarily through its impact on agriculture and health (Diamond, 1997; Sachs, 2001); the role of economic integration in driving convergence (Sachs and Warner, 1995; Frankel and Romer, 1999) and the power of institutional quality in the determination of economic

\footnotetext{
*Correspondence to: Jamus Jerome Lim, Mailstop G8-801, 1818 H St NW, Washington, DC 20433. E-mail: jlim@worldbank.org

${ }^{1}$ As opposed to 'proximate' determinants found in extended Solow-style growth regressions (Mankiw et al., 1992), such as the capital-labour ratio and human capital.
} 
growth outcomes (Acemoglu et al., 2001; Rodrik et al., 2004). Each of these factors is likely to be important in its own right; nonetheless, the primacy of institutions appears to have been overwhelmingly accepted by most researchers working in the area. As Rodrik et al. $(2004$, pp. 135,141$)$ claim triumphantly, 'the quality of institutions trumps everything else... [i]nstitutions trump geography and openness'. ${ }^{2}$

Part of the problem of satisfactorily identifying the channels of transmission is precisely the complexity of interactions between each of these constituent factors. The issue, therefore, boils down to the choice of instruments used for each deep determinant. ${ }^{3}$ The literature has introduced several instruments to this effect. The distance from the equator and malarial risk are often used as instruments for gauging the impact of physical geography. Economic integration is instrumented with the predicted trade/GDP share, as determined by the gravity equation. Instruments for institutional quality include the mortality rate of colonial settlers and the extent of (English and European) ethnolinguistic fractionalisation within the population.

The success of empirical work in establishing the centrality of institutions nonetheless raises another important question: what sorts of institutions matter for growth? After all, the notion of institutions pursued in the literature is diverse. Acemoglu and Johnson (2005) draw a distinction between property rights and contracting institutions, and find that the former dominates in terms of its effect on long-run economic growth. Persson and Tabellini (2006) instead consider parliamentary versus presidential systems of representation, and find that presidential systems tend to grow faster. Glaeser et al. (2004) make the argument that the pertinent distinction is that between institutional quality as opposed to constraints.

In contrast to these papers, we argue that the key difference is one between political-economic and political institutions. More specifically, we regard the politicaleconomic institutions that govern economic norms and rules-legal frameworks, bureaucratic efficacy, curbs on corruption and the regulatory burden-as distinct from political institutions, which is primarily that of democratic representation. While weak political-economic institutions are likely to impose real costs on economic relationships in society, features of a democratic political regime - such as checks and balances, electoral rules and federalism - seem to be of secondary importance to economic life. In addition, sound political-economic institutions could conceivably exist in predominantly non-democratic settings; countries that appear to exhibit such qualities would include Singapore, Tunisia and Jordan. Therefore, while the finer distinctions made by Acemoglu and Johnson (2005) and Persson and Tabellini (2006) are interesting in their own right, we regard our distinction as more fundamental.

This paper seeks to contribute to the debate on the different fundamental drivers of economic growth. In particular, our distinction between political-economic and political institutions allows us to determine if economies exhibiting either of the two-or bothare more likely to experience superior or inferior economic performance, while controlling for geographic endowment and economic integration. Using both cross-sectional as well as panel datasets, we find that while institutions are significant predictors of economic

\footnotetext{
${ }^{2}$ This does not diminish the view of a small minority who continue to argue for the importance of geographic factors. Sachs (2003, p. 10), for example continues to argue that ' $\mathrm{t}$ ] here is good theoretical and empirical reason to believe that the development process reflects a complex interaction of institutions, policies and geography'.

${ }^{3}$ There is also reason to believe that data format-whether time series or cross-sectional-might influence the results as well. Time series and panel data are more likely to capture the dynamic determination of per capita income and growth, while cross-sectional data are more suitable for estimating static levels of national income.
} 
performance, democracy is not. This result is robust to a range of specifications and measures, and is stable across both sets of data.

The debate on the complementarities between economic and political freedom, which in turn spurs growth, goes back to Hayek (1944) and Friedman (1962). More recently, Barro (1996) has explored the manner in which democracy can serve as a fundamental determinant of economic growth, and the papers in the volume edited by Rivera-Batiz and Rivera-Batiz (2002) argue that political participation may evoke economic development in and of itself.

A priori, there is little reason to believe that democratic nations should necessarily grow faster or slower than their non-democratic counterparts. Indeed, a quick glance at the bilateral data alone (Figure 1) suggests that it is difficult to discern if there exists any clear relationship between GDP per capita and the level of democratic development. Theory, in and of itself, offers little help. Przeworski and Limongi (1993) provide four main channels whereby democracy affects economic growth: first, it offers protection from a predatory autonomous authoritarian ruler (positive); second, it potentially unleashes pressures for immediate consumption, thus undermining investment and growth (negative); third, it removes the insulation of the state from particularistic pressures (ambiguous) and fourth, it may have an influence on property rights, which in turn might have a role to play in fostering growth (ambiguous).

Formal models that seek to clarify these channels exist. Using a general equilibrium, endogenous growth model, Rivera-Batiz (2002) shows that democracy raises growth by constraining the actions of corrupt officials. This constraint, in turn, stimulates technological change and thus spurs economic growth. In the model of Persson and Tabellini (1994), redistributive (distortionary) taxation in democracies leads to a deceleration of growth due to a depression of after-tax return to private investment. Alesina and Rodrik (1994) approach the problem using a model where growth occurs through public and private sector investment in physical capital. They obtain a similar prediction: Voting in democracies lead to a choice of a tax rate on capital that is to the right of the growth-maximising one. Thus, there is an inverse relationship between inequality and growth, and - assuming a median-voter mechanism-this implies that democracies should tend to grow slower. Moreover, special interest pressures in democracies can lead to rent seeking, which results in inefficient equilibrium outcomes, undermining growth (Parente and Rui, 2006).

These findings, however, are not definitive. A monotonically positive relation between growth and inequality/democracy is possible if voting leads to a higher expenditure on public education (financed by nondistortionary taxation), which then fuels growth (Verdier and Saint-Paul, 1993). Acemoglu and Robinson (2000) model the aforementioned ambiguity of democracy on growth through the positive impact of majority voting on the expansion of education and hence a country's stock of human capital, mitigated by the negative impact of growth-retarding systems of income redistribution. ${ }^{4}$ Finally, Gradstein (2007) models democracies as supportive for protection of private property rights, thus ensuring larger investment and higher growth.

The empirical literature on the relationship between democracy and growth is large. Most early studies are mixed: Some find that democratic regimes tend to grow faster

\footnotetext{
${ }^{4}$ Glaeser et al. (2004) have made the case that it is in fact human capital that leads to institutional improvements, and not the other way round. Our view is that while human capital may be a predictor of democratic development, it is far from clear that it is a convincing fundamental, as opposed to proximate, determinant of economic growth.
} 
(a)

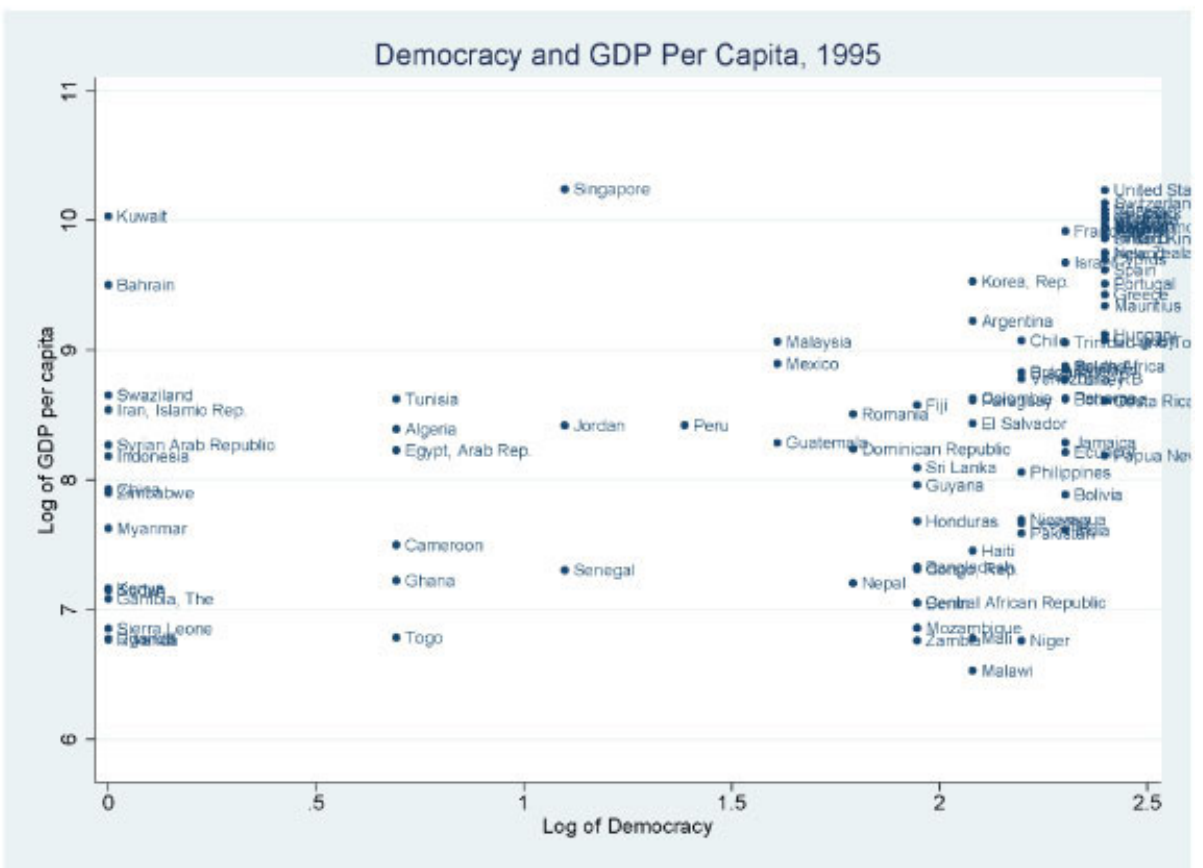

(b)

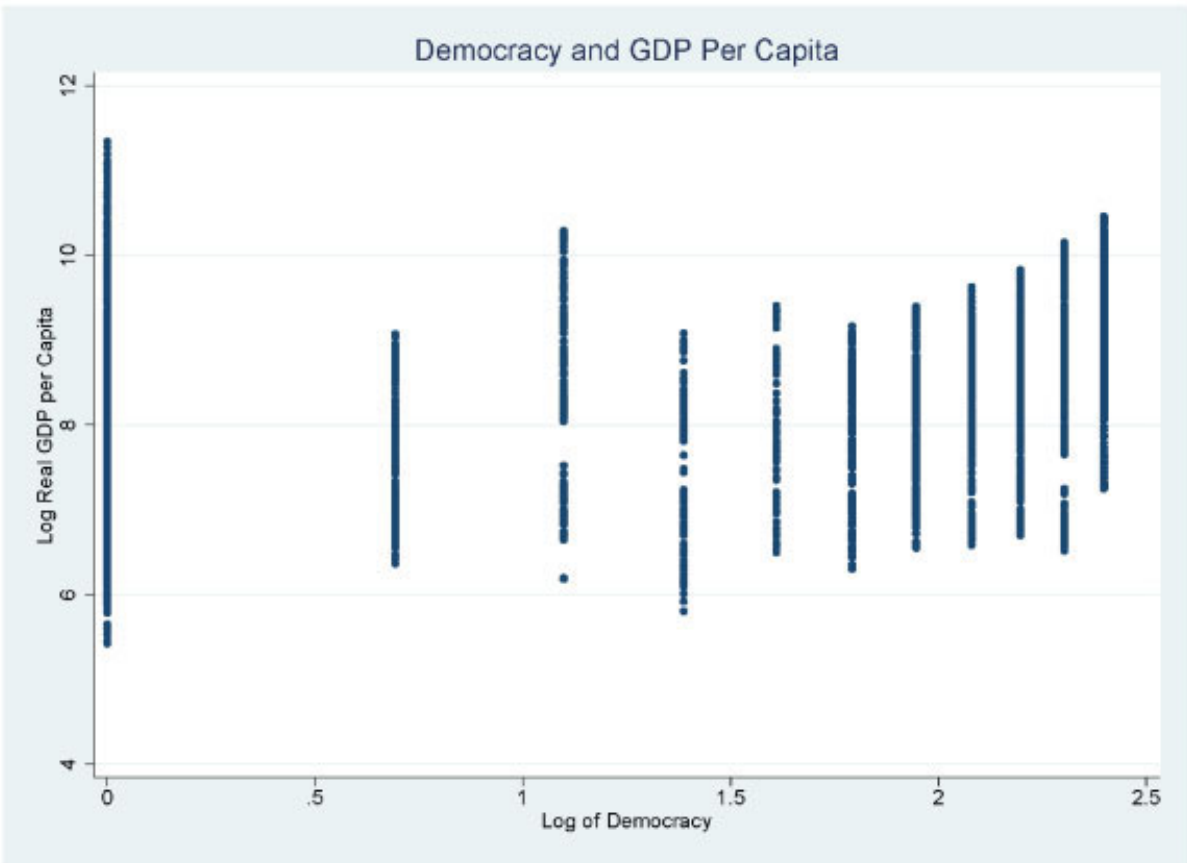

Figure 1. Relationship between democracy and GDP per capita. (a) Cross-sectional for 97 countries, 1995. (b) Pooled panel for 159 countries, 1950-2003. This figure is available in colour online at www.interscience.wiley.com/journal/jid 
(Knack and Keefer, 1995), while others report a weakly significant negative relationship (Barro, 1996). ${ }^{5}$ These earlier studies are, however, racked with measurement, estimation and endogeneity problems (Przeworski and Limongi, 1993). More specifically, the measurement of democracy and economic growth is plagued by potential reverse causality problems. For example, greater economic integration and institutional quality may imply a superior environment for the development of democracy; furthermore, economic development may plant the seed of democratic reform. At the same time, democratic outcomes may well have an impact on the rate of economic growth, as discussed above.

More recent research has taken these charges more seriously. Henisz (2000) employs three-stage least squares to examine how political constraints shape growth, while Vega-Gordillo and Álvarez Arce (2003) consider how economic and political freedom (Granger) cause growth. Rodrik and Wacziarg (2005) examine the growth effects of democratic transitions using fixed effects models, while Persson and Tabellini (2007) exploit propensity matching to consider such regime changes. Both find a positive effect of democratic transitions on growth outcomes. In a slightly different vein, Mobarak (2005) establishes a positive relationship between democracy and growth volatility. The work that is probably most closely associated with the approach of this study is that of Butkiewicz and Yanikkaya (2006). In particular, the authors consider decomposing institutions into measures associated with either rule of law or democracy. However, while their paper considers institutions in significant detail, measures of integration are given short shrift and geography is not considered at all. This highlights a more general difference: While differing in estimation strategies, most of these papers introduce democracy into a vector of proximate covariates, as opposed to the fundamental determinants approach adopted here.

The main empirical contributions of this study are twofold. First, we account for endogeneity in the cross-section by introducing several new instruments for democracy. We consider three potential instruments: government fractionalisation, military spending as a fraction of government expenditures and predicted democracy levels. Why? Democracies are likely to demonstrate greater levels of political participation than totalitarian regimes (Usher, 1981). Similarly, healthy democracies tend to have a lower level of military spending as share of government expenditures (Bueno de Mesquita et al., 1999). Finally, by utilising predicted democracy levels from a regression based on determinants of democracy, we are able to obtain a potentially strong instrument that is highly correlated with actual quantitative or qualitative measures of democracy.

Second, we address endogeneity in the panel by using lagged values of the endogenous variables as instruments for the variables themselves. This is possible in a panel setting, since lags of the regressors are orthogonal to the error term and can hence serve as valid instruments. By drawing instruments from within the dataset, we are able to extend the inferences concerning the fundamental determinants to a much larger sample.

The rest of this paper is structured as follows. Section 2 will provide an overview of the empirical model used in the present study. This is followed by a discussion of the dataset, estimation technique and the main results (Section 3). A final section concludes the paper with some reflections on the findings.

\footnotetext{
${ }^{5}$ In a review of the empirical literature on democracy and growth, Brunetti (1997) finds that the evidence is very truly mixed: of the 17 papers considered, those that find either positive or negative effects number four each, while the remainder find no effect.
} 


\section{EMPIRICAL MODEL}

The main empirical model is a variant of that in Rodrik et al. (2004), to accommodate dynamic features. The core specification for the (fundamental determinants-based) growth regression is:

$$
\log y_{i t}=\alpha y_{i, t-1}+\beta_{0}+\beta_{1} \mathrm{INS}_{i t}+\beta_{2} \mathrm{INT}_{i t}+\beta_{3} \mathrm{GEO}_{i}+\beta_{4} \mathrm{DEM}_{i t}+\varepsilon_{i t}
$$

where $|\alpha|<1, y_{i t}$ is the per capita income in country $i$ at time $t, \mathrm{INS}_{i t}, \mathrm{INT}_{i t}, \mathrm{GEO}_{i}$ and $\mathrm{DEM}_{i t}$ are the deep determinants of institutional quality, economic integration, physical geography and democratic development, respectively, and $\varepsilon_{i t}$ is an error term given by

$$
\varepsilon_{i t}=\mu_{i}+\eta_{i t}
$$

which comprises both fixed effects $\mu_{i}$ and idiosyncratic $\eta_{i t}$ components, and $E\left(\mu_{i}\right)=E$ $\left(\eta_{i t}\right)=E\left(\mu_{i} \eta_{i t}\right)=0, E\left(\eta_{i s} \eta_{i t}\right)=0 \forall s \neq t$ and $E\left(y_{i 1} \eta_{i t}\right)=0 \forall t=2, \ldots, T$.

When we constrain time to a single period, Equation (1) simplifies to an extended version of the special case considered in Rodrik et al. (2004): ${ }^{6}$

$$
\log y_{i}=\beta_{0}+\beta_{1} \mathrm{INS}_{i}+\beta_{2} \mathrm{INT}_{i}+\beta_{3} \mathrm{GEO}_{i}+\beta_{4} \mathrm{DEM}_{i}+\varepsilon_{i}
$$

Identification is achieved in this static model with first-stage regressions using exogenous instruments given by

$$
\begin{gathered}
\mathrm{INS}_{i}=\phi_{0}+\phi_{1} \mathrm{SM}_{i}+\phi_{2} \mathrm{CONST}_{i}+\phi_{3} \mathrm{DEMDEV}_{i}+\phi_{4} \mathrm{GEO}_{i}+v_{i} \\
\mathrm{INT}_{i}=\theta_{0}+\theta_{1} \mathrm{CONST}_{i}+\theta_{2} \mathrm{SM}_{i}+\theta_{3} \mathrm{DEMDEV}_{i}+\theta_{4} \mathrm{GEO}_{i}+v_{i} \\
\mathrm{DEM}_{i}=\lambda_{0}+\lambda_{1} \mathrm{DEMDEV}_{i}+\lambda_{2} \mathrm{SM}_{i}+\lambda_{3} \mathrm{CONST}_{i}+\lambda_{4} \mathrm{GEO}_{i}+\zeta_{i}
\end{gathered}
$$

where $\mathrm{SM}_{i}$ is a measure of settler mortality utilised by Acemoglu et al. (2001) as an instrument for institutional quality, $\mathrm{CONST}_{i}$ is the predicted trade volume according to a gravity specification, used by Frankel and Romer (1999) as an instrument for economic integration and $\mathrm{DEMDEV}_{i}$ is an instrument for the level of democratic development of a country, which is one of the following: (a) government fractionalisation as proxied by the Herfindahl Index of government; (b) military spending as a fraction of total government expenditures and (c) predicted level of democracy, estimated using the specification of Barro (1999), which for convenience is reproduced here:

$$
\operatorname{DEMDEV}_{i t}=\psi_{0}+\psi_{1} \operatorname{DEMDEV}_{i, t-T}+\psi_{2} \operatorname{DEMDEV}_{i, t-2 T}+\psi_{3} \mathbf{X}_{i, t-T}+\xi_{i t}
$$

where for country $i$ at time $t$, the current level of democratic development, DEMDEV ${ }_{i t}$ is determined by the previous levels of democratic development, lagged by $T$ or $2 T$ periods (where $T$ is taken to be 5 years), and $\mathbf{Z}_{i, t-T}$ is a vector of previous-period variables that influence the extent of democracy, and $\xi_{i t}$ is a random error term. The $\mathbf{Z}_{i, t-T}$ vector used in this paper follows the baseline specification of Barro (1999, p. S165), which includes the logarithm of real per capita GDP 5 years prior, measures of educational attainment 5 years prior (specifically, these are the years of primary schooling for persons aged 25 and over, and the gap between the years of primary school attainment between males and females

\footnotetext{
${ }^{6}$ Note that we have chosen to drop the lagged-dependent variable from the right-hand side of Equation (1). This is both to remain consistent with Rodrik et al. (2004), as well as for practical reasons; given the significant lags that are likely to operate with respect to these deep determinants of growth, the inclusion of a lagged-dependent variable in the static model is likely to swamp the subtle effects that would otherwise be picked up.
} 
aged 25 and over), a measure of the urbanisation rate 5 years prior, a measure of country size given by the logarithm of the 5-year earlier population level and a dummy for oil-exporting countries. $^{7}$

In order to identify the dynamic model, we exploit its temporal nature to retrieve an instrument set based on the lags of the endogenous variables:

$$
\mathbf{Z}_{i}=\left[\begin{array}{cc}
0 & \mathbf{0} \\
\mathbf{0} & \mathbf{W}_{i}
\end{array}\right], \quad \mathbf{W}_{i}=\left[\operatorname{diag}\left(\Delta \mathbf{W}_{i, t+1} \cdots \Delta \mathbf{W}_{i, T}\right)\right]
$$

where $\mathbf{W}_{i t}=\left[\mathrm{INS}_{i t} \mathrm{INT}_{i t} \mathrm{DEM}_{i t}\right]$ are the time-varying deep determinants, and we supplement $\mathbf{Z}_{i}$ (in levels) with the purely exogenous (time-invariant) instrument $\mathrm{GEO}_{i}$ and (in some specifications) time dummies $\mathbf{T}_{i}=[t, t+1, \ldots, T]$. The instrument matrix $\mathbf{Z}_{i}$, together with the exogenous instruments $\mathrm{GEO}_{i}$ and $T_{i}$, correspond to a set of moment conditions that can be used in the estimation process using generalised method of moments (GMM).

As stressed by Rodrik et al. (2004), the core specification given by Equations (1), (3) and (4) represent a natural framework for estimating the impact of the deep determinants of institutional quality, economic integration, geographic influences and democratic development. The symmetry in this specification allows each variable an equal chance of exerting an influence on the economic development of any given country.

\section{ESTIMATION FINDINGS}

\subsection{Datasets}

We make use of two distinct datasets, corresponding to each of the two main estimation procedures. The single-period cross-section is an augmented version of that used in Rodrik et al. (2004), and so the finer details will not be repeated here. The data comprise up to 91 countries for the year 1995. For completeness, we will briefly discuss the key variables.

Institutional quality is measured by a composite indicator (ranging from -2.5 to 2.5 , with higher values indicating stronger institutions) that captures, inter alia, property rights protection and rule of law, provided by Kaufmann et al. (2007); it is instrumented by the mortality rate of soldiers, bishops and sailors in European colonies between the 17th and 19th centuries (Acemoglu et al. 2001) and the extent of ethnolinguistic fractionalisation (Hall and Jones, 1999). Economic integration is proxied by an openness measure of the ratio of trade to GDP, measured in real PPP terms (Heston et al., 2006) and is instrumented with predicted bilateral aggregate trade shares, as estimated by a variant of the gravity equation (Frankel and Romer, 1999). Geography is itself a natural instrument, and in the benchmark cross-section, it is taken to be the latitudinal distance from the equator of the capital city, as provided by the World Bank's World Development Indicators (WDI).

The actual level of democracy is taken from the Polity IV dataset (Marshall and Jaggers, 2005). The instruments are: (a) the Herfindahl Index of government, which is the sum of squared seat shares of all parties in the government (higher values suggest a more unified government and hence lower levels of democratic participation), and is provided by the

\footnotetext{
${ }^{7}$ See Table 1 of Barro (1999), and the discussion from pp. S164-S166. Note that Barro uses two indices of democratic development as dependent variables: Electoral rights and civil liberties, obtained from Freedom House. In this paper, we have instead used a composite democracy index provided by Marshall and Jaggers (2005). 
Table 1. Determinants of democracy

\begin{tabular}{lcc}
\hline & $(D 1)$ & $(D 2)$ \\
\hline Five-year lag of democracy & $0.558(0.10)^{* * *}$ & $0.530(0.12)^{* * *}$ \\
Ten-year lag of democracy & $-0.013(0.07)$ & $0.003(0.06)$ \\
Log GDP per capita & $-0.074(0.07)$ & $-0.095(0.06)$ \\
Gap between male/female primary schooling & $-0.021(0.01)^{* *}$ & $-0.019(0.01)^{*}$ \\
Years of primary schooling & & $0.010(0.06)$ \\
Urbanisation rate & & $-0.037(0.04)$ \\
Log population & & $-0.012(0.04)$ \\
Oil country dummy & $1.605(0.56)^{* * *}$ & $-0.105(0.12)$ \\
Constant & 0.536 & $2.061(0.82)^{* *}$ \\
Adjusted $R^{2}$ & 93 & 0.524 \\
$N$ & 93 \\
\hline
\end{tabular}

Note: Huber-White (robust) standard errors reported in parentheses. A constant term was included in the regressions, but not reported.

${ }^{*}$ Indicates significance at 10 per cent level; ${ }^{* *}$ indicates significance at 5 per cent level; and ${ }^{* * *}$ indicates significance at 1 per cent level.

World Bank database of political institutions (Beck et al., 2001); (b) Military spending as a share of total government expenditure from the WDI and (c) predicted level of democracy. The variables used for the vector of controls $\mathbf{X}$ are from Barro and Lee (1996) (educational attainment measures), the World Bank WDI and the IMF International Financial Statistics (IFS). Lagged democracy levels utilise the 1985 and 1990 levels of democracy from the Policy IV dataset.

The predicted level of democracy was regressed on a subset of the data for which observations for the independent variables were available. As a simple robustness check, two specifications for the democracy regression were run: (Dl) a leaner model that includes just lagged democracy variables, income per capita and a measure of educational attainment; and (D2) the baseline model of Barro (1999), as discussed above. The results are reproduced in Table 1.

In general, the regression provided a reasonable fit (adjusted $R^{2}$ for the preferred specification (D2) was 0.524). With the exception of the 10-year lagged democracy level, $\log$ GDP per capita, and the oil country dummy, the coefficients had the expected signs, similar to that of Barro (1999). Since the latter two (GDP and oil dummy) coefficients were statistically insignificant, the expected signs were not major issues. Moreover, the point estimate for the 10-year lag of democracy was relatively small, and only marginally significant, and its unexpected sign is unlikely to affect the value of the predicted democracy as an instrument.

Table 2 summarises the quality of the instruments used in a correlation matrix. As can be seen, the predicted democracy instrument is by far the superior instrument for actual democracy levels; as such, it will be the instrument of choice for the bulk of the cross-sectional estimations. This strong relationship is also captured in Figure 2. Figure 3 provides a graphical depiction of the relationship between the various instruments and GDP per capita.

The multi-period panel comprises 128 countries between the years 1984 and 2002, for an unbalanced panel of up to 2091 observations. The integration, geography and democracy measures were obtained from the same sources (Heston et al., 2006, the WDI and Marshall 
Table 2. Cross correlations for democratic development instruments

\begin{tabular}{lccccc}
\hline & GDP/capita & $\begin{array}{c}\text { Actual } \\
\text { democracy }\end{array}$ & $\begin{array}{c}\text { Government } \\
\text { fractionalisation }\end{array}$ & $\begin{array}{c}\text { Military } \\
\text { expenditure }\end{array}$ & $\begin{array}{c}\text { Predicted } \\
\text { democracy }\end{array}$ \\
\hline GDP/capita & 1.000 & & & & \\
Actual democracy & $0.420(0.00)^{* * *}$ & 1.000 & & & \\
Government fractionalisation & $-0.071(0.52)$ & $-0.134(0.20)$ & 1.000 & 1.000 & \\
Military expenditure & $-0.183(0.10)^{*}$ & $-0.375(0.00)^{* * *}$ & $0.030(0.80)$ & 0.000 \\
Predicted democracy & $0.631(0.00)^{* * *}$ & $0.752(0.00)^{* * *}$ & $-0.190(0.08)^{*}$ & $-0.269(0.02)^{* *}$ & 1.000 \\
\hline
\end{tabular}

Note: $p$-values reported in parentheses.

${ }^{*}$ Indicates significance at 10 per cent level; ${ }^{* *}$ indicates significance at 5 per cent level; and ${ }^{* * *}$ indicates significance at 1 per cent level.

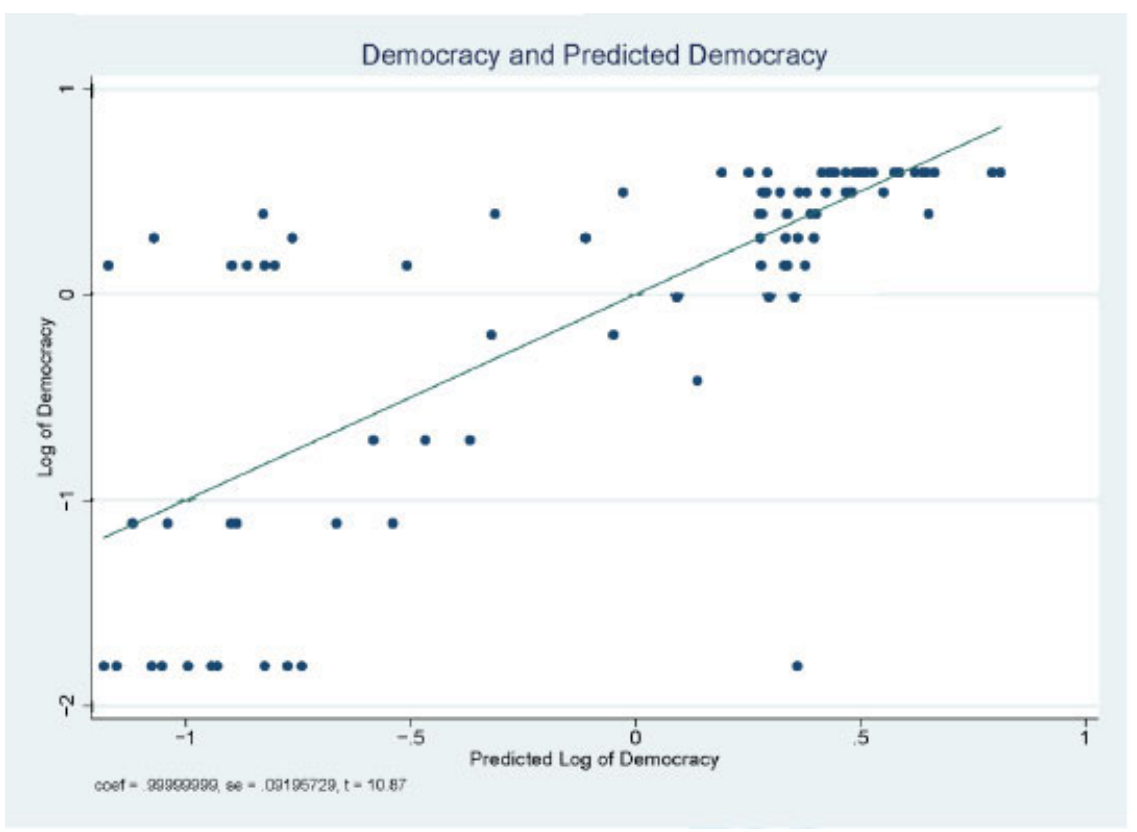

Figure 2. Actual and predicted democratic development, 1995, with fitted regression line. This figure is available in colour online at www.interscience.wiley.com/journal/jid

and Jaggers, 2005, respectively). Unfortunately, the composite governance measure used for institutional quality in the cross-section Kaufmann et al. (2007) is only available for seven discontinuous years (1996, 1998, 2000, 2002-2006), and so is not well suited for panel analysis. We substitute the institutional measure with an alternative measure compiled from the International Country Risk Guide (Political Risk Services, 2003), which spans a much longer period (1984-2002). This composite indicator (ranging from 0 to 3.9, with higher values indicating stronger institutions) accounts for, inter alia, the quality of bureaucracy and rule of law. ${ }^{8}$

\footnotetext{
${ }^{8}$ In any event, the correlation between these two measures is very strong: 0.88 , significant at 1 per cent.
} 


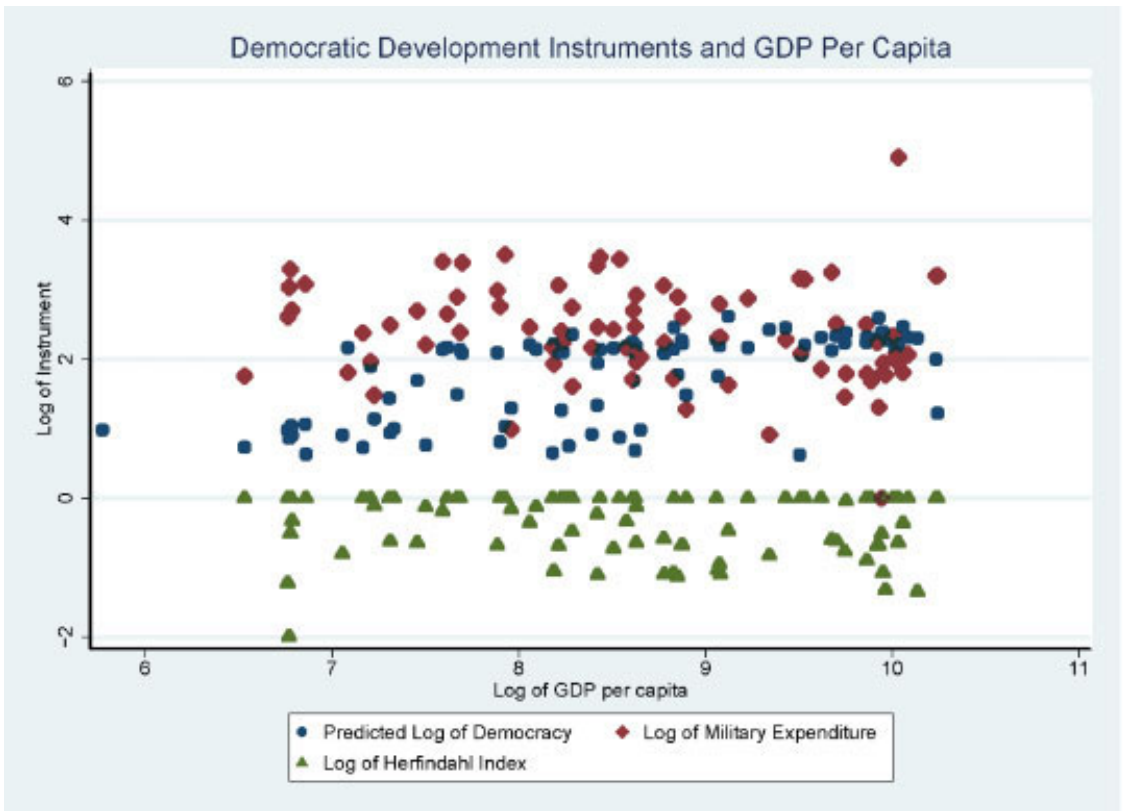

Figure 3. Democratic development instruments and relation to GDP per capita, 1995. This figure is available in colour online at www.interscience.wiley.com/journal/jid

\subsection{Estimation Methodology}

To address the econometric issues raised in the introduction, the model in Equation (1) is estimated with two estimation procedures that take into account endogeneity concerns: (a) instrumental variables using two-stage least squares (2SLS); and (b) system general method of moments (System GMM) (Arellano and Bover, 1995; Blundell and Bond, 1998). ${ }^{9}$ These approaches correspond, respectively, to the static and dynamic versions of Equation (1).

The predicted bilateral trade volume instrument was constructed by estimating the gravity model using standard panel regression techniques (Frankel and Romer, 1999). The democratic development instrument was estimated with OLS. ${ }^{10}$ The cross-sectional growth regressions were estimated with both OLS and 2SLS with instrumental variables, while the panel growth regressions were estimated with OLS, fixed effects and System GMM.

Static regressions controlled for heteroskedasticity with Huber-White robust standard errors, and panel estimates controlled for both heteroskedasticity and autocorrelation. Panel estimates also made finite sample corrections and applied the forward orthogonal

\footnotetext{
${ }^{9}$ Due to the time invariance of the integration variable, and its importance in the core specification (1), it is not possible to use the alternative - and more popular-difference estimator (Arellano and Bond, 1991).

${ }^{10}$ Barro (1999) actually uses the seemingly unrelated regression (SUR) method, which allows for the error term in country $i$ at time $t$ to be correlated with the error terms of the same country at a different time $t$ '. Since the estimation only required predicted democratic development values for 1 year (1995), OLS was sufficient for our purposes.
} 
Table 3. Descriptive statistics for GDP per capita for cross-section

\begin{tabular}{lcc}
\hline & Democratic & Nondemocratic \\
\hline Mean & 8.750 & 7.893 \\
Standard deviation & 1.062 & 0.724 \\
Minimum & 6.532 & 6.771 \\
Maximum & 10.233 & 9.066 \\
$N$ & 65 & 26 \\
\hline
\end{tabular}

Note: Democracies were classified as those with democracy level greater than 5 , on a scale of 0-10, as given in the Polity IV dataset (Marshall and Jaggers, 2005).

deviations transform, which preserves sample size given the unbalanced nature of the panel.

\subsection{Static Model Results}

As discussed in the introduction, there is no clear reason why democracies need necessarily exert a direct impact on economic performance. Table 3 divides the sample into democracies and non-democracies and provides summary statistics for the two groups for the key variables of interest, real GDP per capita. The numbers underscore the ambiguity of the data: while democracies as a group appear to have a higher mean real GDP per capita, they also demonstrate a wider range of performances. Furthermore, the lowest level of GDP per capita among democracies (corresponding to Uruguay) is lower than the lowest among non-democracies (corresponding to Rwanda).

Table 4 reports our benchmark results. These are: (C1) OLS regression of GDP per capita on institutions, integration, geography and democracy given by the special case of Equation (1); (C2) IV regression with settler mortality and government fractionalisation as instruments for institutions and democracy, respectively; (C3) Specification $(C 2)$, but with democracy instrumented by military expenditure; $(C 4)(C 2)$, but with democracy instrumented by predicted democracy; $(C 5)(C 2)$, with democracy instrumented by the all three democratic development instruments; (C6)-(C8) analogous regressions to $(C 2)-(C 4)$, but with ethnolinguistic fractionalisation as an instrument for institutions.

There are several points worth noting about the static model findings. First, the results for the prominence of institutions echo as in the findings of Rodrik et al. (2004): in six of the eight specifications, institutional quality exerts a positive and statistically significant influence on economic growth. The effect is also economically significant: the average of the coefficient on all specifications is 1.135 , implying that a one-point increase in institutional quality increases GDP per capita in the excess of a 100 per cent. Moreover, Hansen $J$-test diagnostics suggest that, with the exception of (C8) (and marginally for $(C 7)$ ), the use of additional instruments did not lead to overidentification, which lends credibility to the estimates.

Second, while the quality of institutions is important, those associated with democracy are demonstrably less so. Point estimates for the democracy variable are statistically significant in only two of the eight specifications, (C5) and (C6); and for both they are only marginally significant (at 10 per cent level). Democracy does nonetheless appear to be positively related to income, even after instrumentation: the coefficients for democratic development are either very slightly negative or positive, and the positive values range 
What Fundamentally Drives Growth? 709

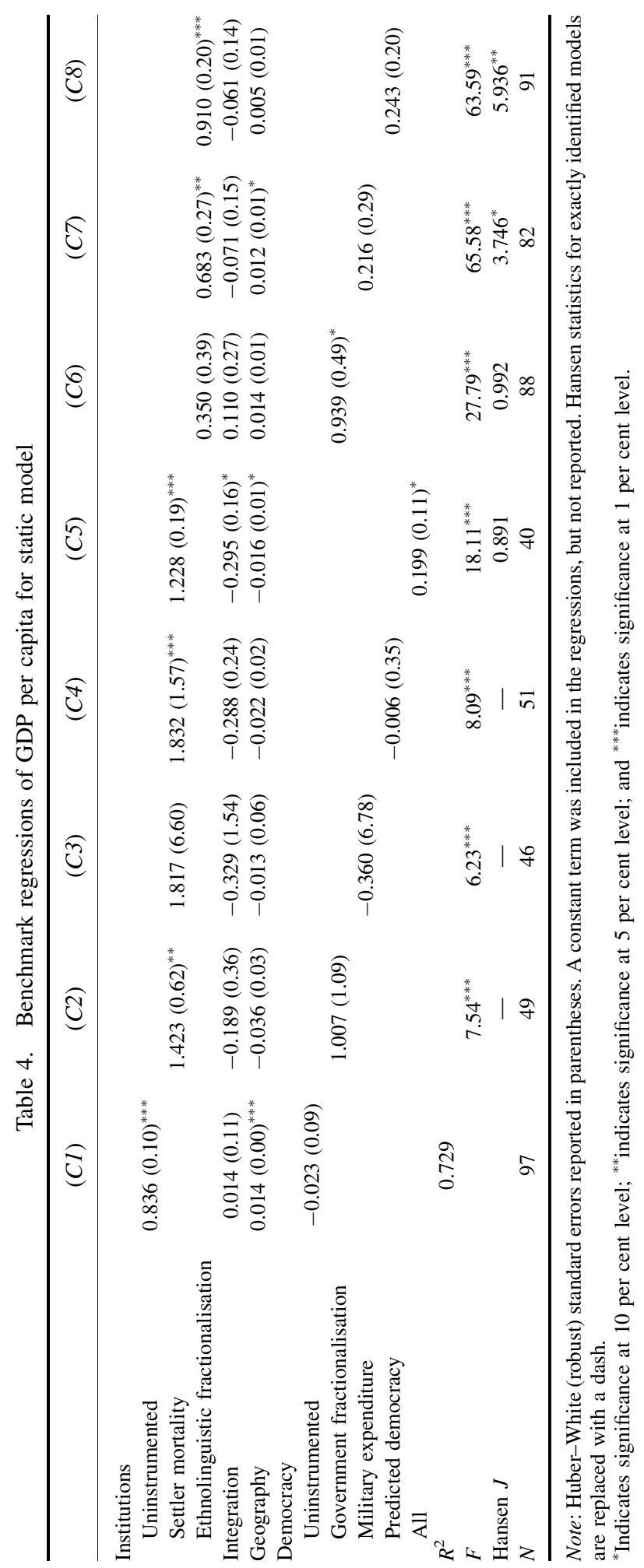


from 0.199 to 0.939 . It is worth noting that the statistically significant coefficient on democracy in (C6) comes at the expense of a significant coefficient on the institutions variable. This outcome could be due to highly correlated measures of both in that particular subsample.

Third, we find, in contrast to Rodrik et al. (2004), that geography and integration are not always 'trumped' by institutions. In three of the specifications, geography enters with a statistically significant coefficient. However, the values and direction of these estimates are not stable. In particular, the sign appears to vary in accordance with the specific subsample considered, with the larger subsample tending to produce the positive coefficients consistent with a priori theory. Similarly, integration does enter into one specification, (C5), with a marginally significant coefficient, although it is incorrectly signed. Since these variables are neither the focus of our study, nor do they show up in sufficient specifications, we reserve judgement on these apparent inconsistencies. We do note, however, that such counterintuitive results were also found by Rodrik et al. (2004).

Fourth, only when we utilise the predicted level of democracy do we yield Anderson LR test statistics (not reported) that reject the null of underidentification $\left(\chi^{2}=2.982\right.$, $p$-value $=0.084)$. This result suggests that instrumenting with predicted democracy provides a better fit, which validates our choice of predicted democracy as the instrument of choice for democratic development (see also Table 2 and Figure 3).

To test the robustness of these findings, Table 5 reports results from a range of robustness checks performed to ascertain the main finding that the political regime, once properly instrumented, does not affect economic performance. The perturbations have been chosen to follow, in the main, those performed in Rodrik et al. (2004). These can be classified into two broad categories: (a) robustness to other deep determinants of growth, such as the legal system (whether this has origins from French civil law or English common law); and (b) robustness to alternative measures of the key deep determinants.

The specifications are, for other deep determinants as controls: (Ral) inclusion of regional dummies for Latin America, Sub-Saharan Africa and East Asia; (Ra2) inclusion of an indicator variable that takes on unity when the legal system has French legal origin; (Ra3) inclusion of an indicator variable that takes on unity when the country was once a colony that was classified by Acemoglu et al. (2001) as neo-European (the United States, Canada, Australia and New Zealand); (Ra4) inclusion of an indicator variable that takes on unity when the country was at war in 1995; (Ra5) inclusion of an indicator variable that takes on unity when the country experienced a revolution or a coup in 1995; (Ra6) inclusion of an indicator variable that takes on unity when the country is an oil exporter, as classified by the IMF.

The specifications for alternative measures are: $(R b 1)$ inclusion of a variable measuring tropical land area; $(R b 2)$ inclusion of an indicator variable that takes on unity when the country is landlocked; $(R b 3)$ inclusion of an index measuring the prevalence of malaria; $(R b 4)$ instrumenting integration with a measure of real openness, taken to be trade openness in PPP terms; (Rb5) instrumenting integration with the Sachs and Warner (1995) measure of trade policy openness and $(R b 6)$ inclusion of two proxies for market size, land area and population.

Where possible, we have reported results for the larger sample using ethnolinguistic fractionalisation as instruments for institutions. However, when these instruments failed the Hansen $J$-test for overidentification, we have reported instead the specification that instruments institutions with settler mortality (which is exactly identified). We also explored additional controls and alternative specifications, such as frost days per year 


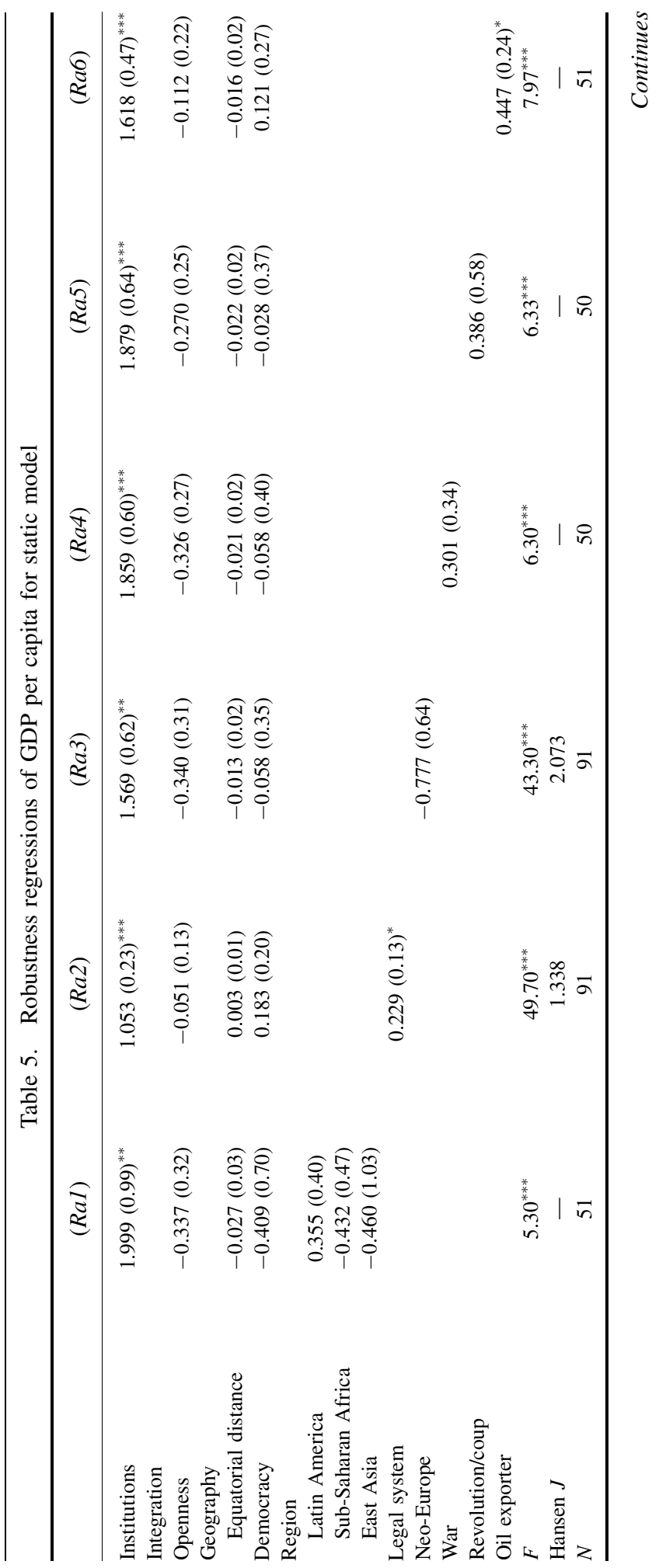




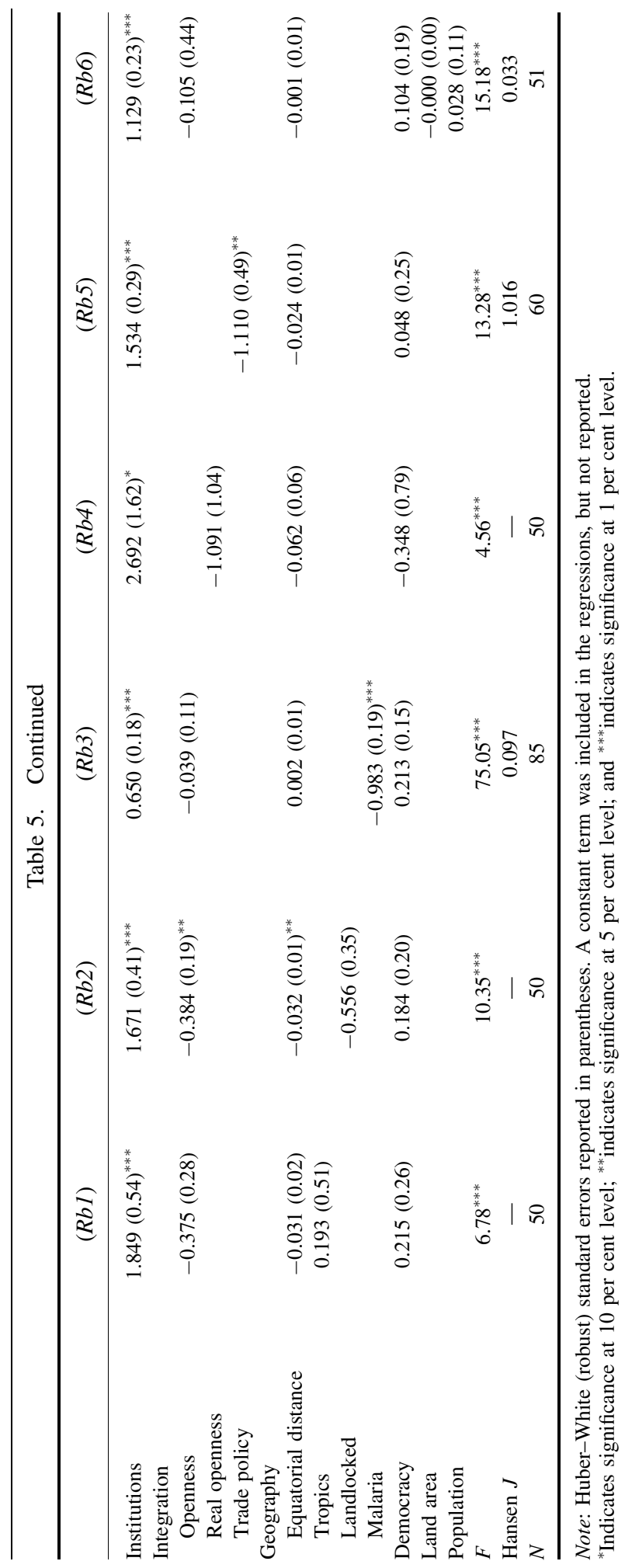


Table 6. Descriptive statistics for GDP per capita for panel

\begin{tabular}{lcc}
\hline & Democratic & Nondemocratic \\
\hline Mean & 8.966 & 8.007 \\
Standard deviation & 0.955 & 1.108 \\
Minimum & 6.589 & 5.806 \\
Maximum & 10.445 & 10.507 \\
$N$ & 1131 & 960 \\
\hline
\end{tabular}

Note: Democracies were classified as those with democracy level greater than 5, on a scale of 0-10, as given in the Polity IV dataset (Marshall and Jaggers, 2005).

(additional geography control) and coloniser identity (additional deep determinant), but these did not produce substantially different outcomes.

The general message that one obtains from the robustness checks is that democracy does not exert a significant influence on economic performance across the cross-section of countries. The coefficient on democracy is not statistically significant across all specifications, and the sign on these coefficients are also not stable.

The quality of institutions continues to be a positive, and significant, fundamental determinant, a result consistent with Rodrik et al. (2004). However, physical geography does appear to be marginally significant for some specifications, although these enter with the incorrect sign. However, the coefficient on the malarial incidence index - the results for $(R b 3)$ - is negative and significant, a result that has been replicated by Sachs (2003) and Carstensen and Gundlach (2006). If disease ecology is the moderating variable by which underdevelopment occurs, then, geography cannot be ruled out as an important determinant to cross-country economic growth outcomes.

Depending on the specification, other determinants do seem to matter. For example, oil-exporting countries do appear to perform better, which suggests that there remain aspects of the African experience that are not captured by the simple empirical model given by Equation (1). Keeping in mind the negative (though insignificant) coefficient on Sub-Saharan Africa, this finding casts doubt on the notion that the resource curse applies uniformly to all natural resources.

\subsection{Dynamic Model Results}

Table 6 presents the summary statistics for GDP per capita for the larger panel data. The results for mean levels of GDP per capita for democracies versus non-democracies are remarkably similar to those reported in Table 3. The standard deviations for per capita GDP for democracies is, however, much smaller; this statistic implies that, for the panel, democracies possess both higher average levels of GDP per capita together with lower variability.

The benchmark results for the panel are reported in Table 7. These correspond to: $(P l)$ OLS regression of GDP per capita on lagged GDP per capita and levels of institutions, integration, geography and democracy given by Equation $(1) ;(P 2)$ fixed effects regression of specification $(P 1)$; $(P 3)$ System GMM estimation of $(P 1)$, with lagged GDP per capita, integration, institutions and democracy instrumented by one-period lagged GMM-style instruments and geography treated as an IV-style instrument; $(P 4)(P 3)$, but with time dummies included as IV-style instruments; $(P 5)-(P 6)(P 4)$, with varying structures of 


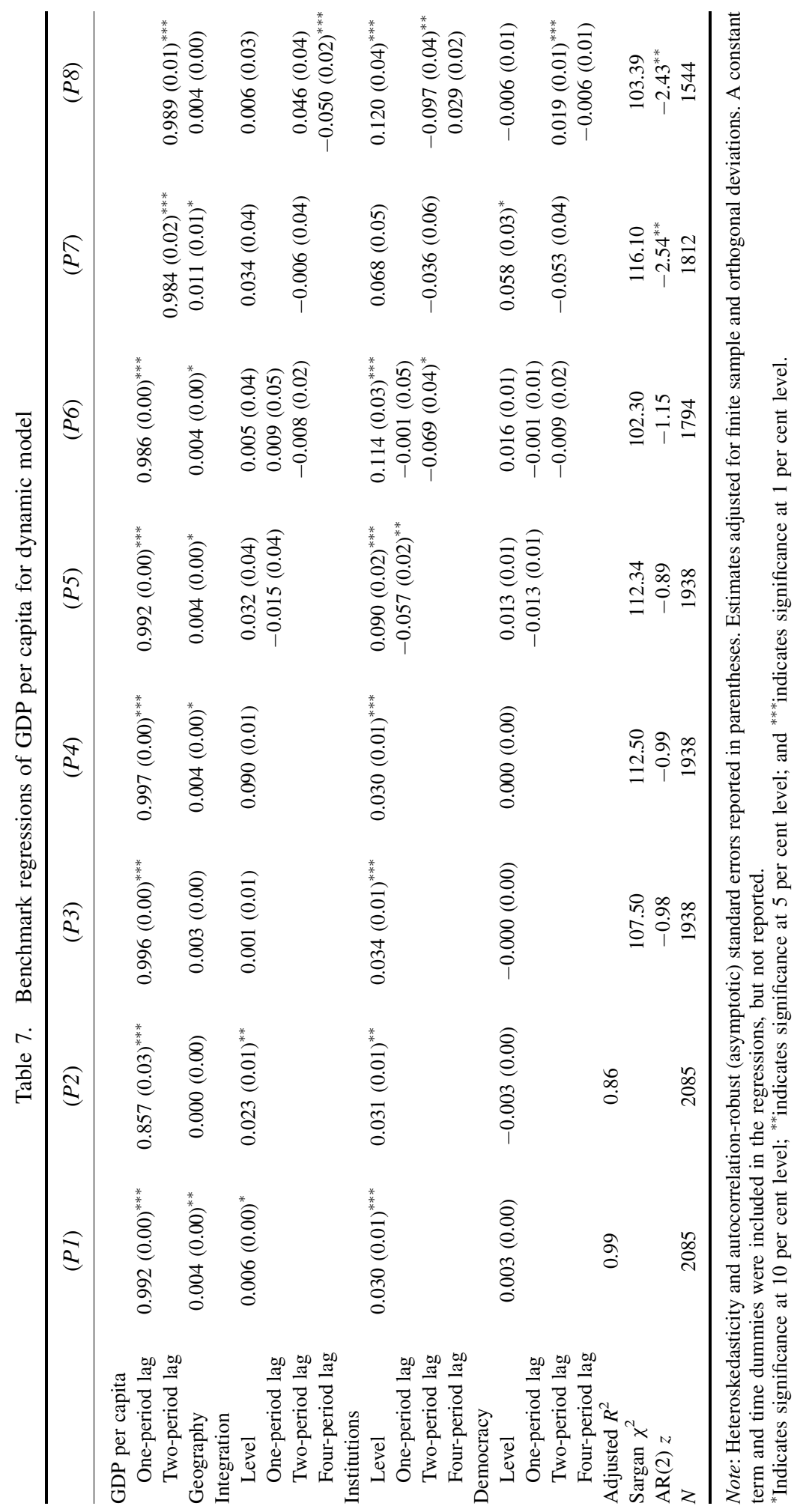


the deep determinants, and instrumented by level through two-period GMM-style lags of the endogenous variables and both geography and time dummies as exogenous IV-style instruments; $(P 7)-(P 8)$ analogous to $(P 5)-(P 6)$, but with a two and four-period lag structure. $^{11}$

The results for the dynamic model are notable for their strong corroboration of the main findings in Section 3.3. As before, institutions appear to be an important fundamental determinant of GDP per capita. With the exception of specification (P7), the level coefficient for institutions enters with a positive and statistically significant coefficient. In addition, the magnitudes are also economically significant, and comparable to that of the static model: the average over all specifications is $e^{0.065}=1.067 .{ }^{12}$ For the specifications with lagged variables-(P5)-(P8) - the coefficients tend to be negative (although not always significant), which suggests that the long-run impact of institutions is weaker than its short-run impact. At first glance, this finding is somewhat surprising, since it is often assumed that the positive impact of strong institutions takes time to diffuse throughout the economy. However, to the extent that weak institutions exert a real, immediate cost on growth, the muted latter-period effects of institutions on income may be less surprising.

Second, democracy is, as before, largely irrelevant as a fundamental determinant of growth. The coefficients are mostly indistinguishable from zero, and in the two specifications where they are significant, the high $z$ scores for the Arellano-Bond test suggests that, with $\operatorname{AR}(2)$ autocorrelation still present, there is a possibility of misspecification in the GMM-style instruments. In addition, the signs of the level coefficients for democracy are no longer stable. As was the case in (C6), the significance of democracy in $(P 7)$ could once again be due to correlated measures of institutions and democracy in the particular subsample.

Third, and in contrast to the static model, both geography and integration appear to be positive determinants of GDP per capita. While these variables are not always statistically or economically significant, their consistency with their theoretically expected signs is reassuring. As before, our results are indicative of the fact that the primacy of institutions does not mean that other fundamental determinants, especially geography, are no longer relevant. This finding also provides some partial vindication of the view of Sachs (2001, 2003), which argues that geography remains an important fundamental determinant, independent of the intervening effects of institutional quality.

Fourth, the results in $(P 1)$ and $(P 2)$ underscore the importance of taking into account endogeneity issues in estimates of Equation (1). While it initially appears that most fundamental determinants (save democracy) are significant determinants of GDP per capita, controlling for possible endogeneity causes measures of integration to completely fall out of the picture (except in the two-period lag of $(P 8)$, where it enters with a wrong sign), while also weakening the influence of geography. We note, however, that coefficient estimates for specification $(P 1)$ and $(P 2)$ are biased upward and downward, respectively, and hence for the theoretical upper and lower bounds that can be used as a check on integrity of the estimates from the other specifications (Bond, 2002).

Tests of the robustness of the dynamic model are reported in Tables 8a and 8b. As far as possible, we have sought to introduce analogous perturbations to those in

\footnotetext{
${ }^{11}$ We have chosen not to run two-step GMM due to well-known finite-sample problems associated with the standard errors of two-step estimates. Indeed, two-step estimates of the model (not reported) suggest significant downward bias in the standard errors, even after effecting the Windmeijer (2005) correction.

${ }^{12}$ As described in the Appendix, the natural $\log$ is taken for the alternative measure of institutions used for the dynamic model.
} 


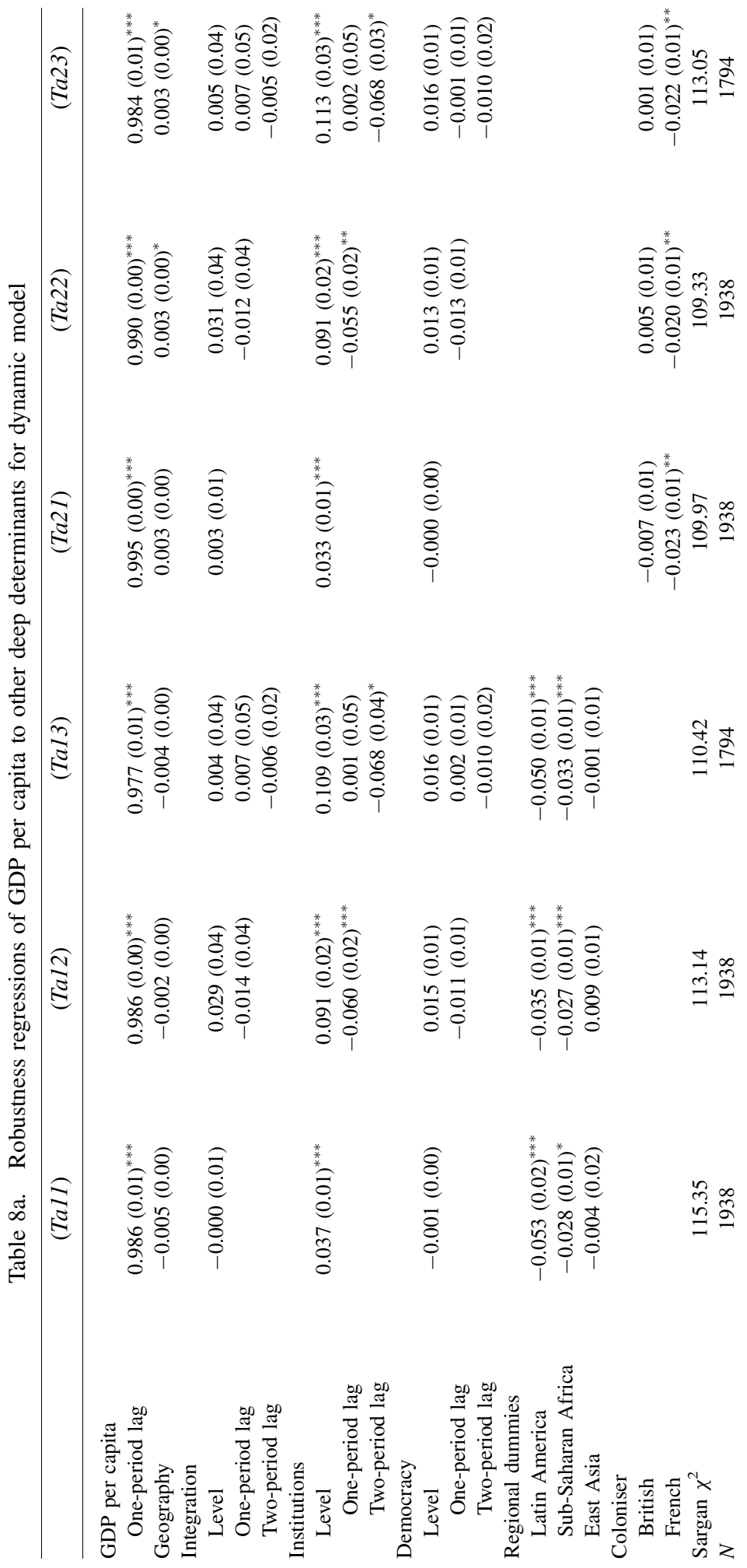




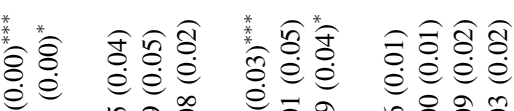




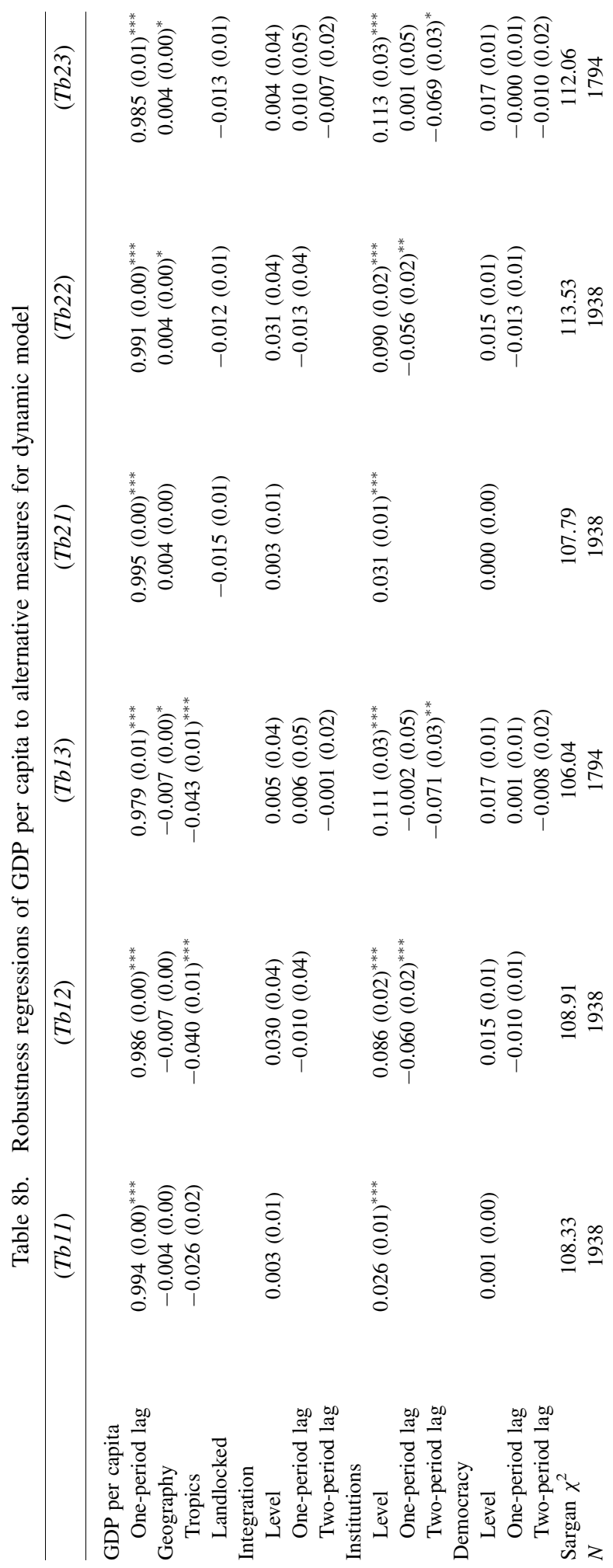


What Fundamentally Drives Growth? 719

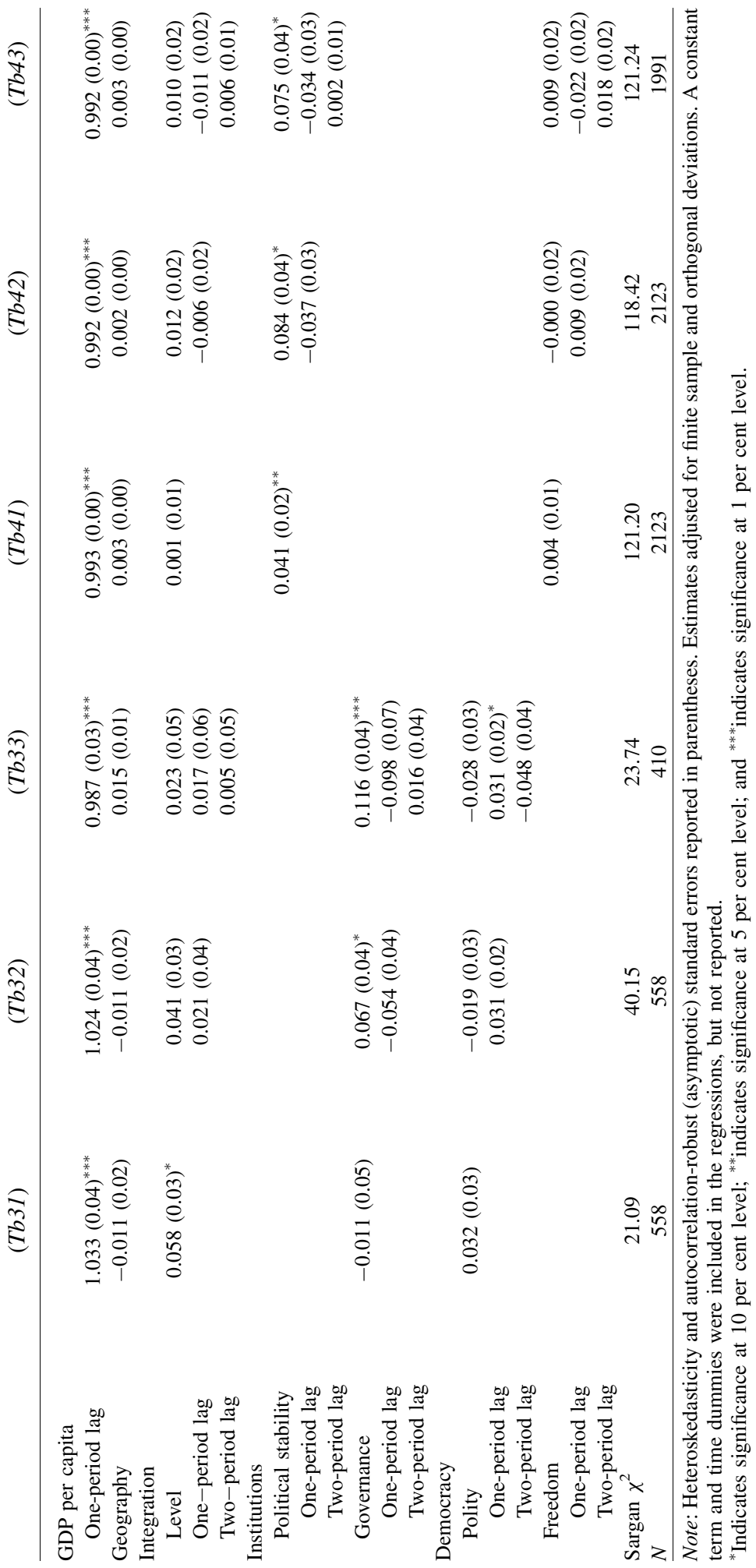


Table 5. As in Table 5, these can be classified into the categories: (a) robustness to other deep determinants; and (b) robustness to alternative measures of deep determinants. ${ }^{13}$

For each robustness check, we ran the three specifications corresponding to $(P 4)-(P 6)$ (reported as sub-specifications $1-3$ in Tables $8 \mathrm{a}$ and $8 \mathrm{~b}$ ). The specific perturbations are as follows: (Tal) inclusion of regional dummies for Latin America, Sub-Saharan Africa and East Asia; ( $T a 2)$ (Ra2) inclusion of an indicator variable for a history of French colonisation; (Ta3) inclusion of an indicator variable for neo-Europe; (Ta4) inclusion of an indicator variable for oil exporters. The specifications for alternative measures are: $(\mathrm{Tb} 1)$ inclusion of a variable measuring tropical area; ( $\mathrm{Tb2}$ ) inclusion of an indicator variable for landlocked countries; (Tb3) substitution of the institutions variable with the governance measure in Kaufmann et al. (2007); (Tb4) substitution of the democracy variable with the freedom index in Freedom House (2007).

The robustness tests do not change the primary finding of this paper: the political regime, once properly instrumented, does not affect economic performance, insofar as compared to other fundamental determinants of growth. This is regardless of the specific measure that we have chosen, since the coefficient on democracy remains insignificant even with an alternative measure (as seen from the results in (Tb4)). Several other findings, however, are of interest, and so will be discussed briefly.

Institutions continue to feature prominently as a significant, positive determinant of growth. As before, the positive effect of institutions diminishes over time, although this effect is not consistently significant across all specifications. Importantly, this result is robust to the alternative measure of institutions that we employ: institutions, as measured by governance, exerts a positive and significant effect in (Tb32) and (Tb33), although in this case the lagged effects are not significant.

Likewise, physical geography does seem to exert an impact on growth outcomes, at least in some specifications. Equatorial distance is positive and significant in (Ta3), and conversely, a larger tropical area reduces GDP per capita — see $(T b 1)$ - in a significant and negative fashion. However, integration does not appear to survive the robustness checks. It enters with a positive sign in only one specification, (Tb31), and only marginally so.

Finally, we note that other additional deep determinants, especially regional dummies and colonial history, do seem to make a difference. The former result is similar to the findings in Section 3.3, although in this case the dummy for Sub-Saharan Africa is not just negative but also statistically significant. The negative coefficient on the dummy for French legal origin is not entirely inconsistent with those of other researchers (Acemoglu et al., 2001), who have argued that British colonies tend to perform better in part because of Britain's care in colonising locations where settlements were possible, which led to British colonies that were not merely extractive, but instead allowed for the development of better institutions.

\footnotetext{
${ }^{13}$ In the interests of space, we have chosen to limit the number of reported robustness tests, as well as test diagnostics. The covariates included in Tables $8 \mathrm{a}$ and $8 \mathrm{~b}$ were chosen based on theoretical as well as statistical significance (consistent with Table 5), and all reported specifications passed the Arellano-Bond test for serial correlation.
} 


\section{CONCLUSION}

Critics of democracies often suggest that democratic pressures are inimical to economic growth, while its strongest proponents tend to overemphasise the role of democracy. ${ }^{14}$ On the surface, the anecdotal evidence seems to support the case of the former: China's sustained rate of growth in GDP, averaging 8 per cent or more over two decades, was achieved while the country was under the rule of an authoritarian regime; while India, the world's largest democracy, had a far more modest record, with poverty rates today still about twice that of China.

The more nuanced view, however, is that democracy is neither necessary nor sufficient on its own to ensure economic performance, nor does it need to be a 'cruel dilemma' (Bhagwati, 2002). Indeed, it sees that any growth-enhancing effects of democracy are conditional on a policy that includes a combination of market-orientated growth strategies - perhaps embodied in pro-growth institutions - and trade openness. Bhagwati (2002, pp. 151-152) offers a candid explanation:

Democracy is not necessarily better for development. Only when combined with markets and openness does democracy offer the best prospect of achieving the efficient, dynamic society that allows development to thrive.

This paper has sought unpack the definition of 'institutions' in order to provide empirical evidence behind the roles that political-economic and purely political institutions play as fundamental drivers of growth. Once we take into account the econometric problems arising from endogeneity, and controlling for other deep determinants such as economic integration and physical geography, our main finding is that (political-economic) institutions exert a significant impact on the level of income, whereas the political institution of democracy is insignificant. Although similar to the findings in Butkiewicz and Yanikkaya (2006), our result that democracy is insignificant is stable across both cross-sectional and panel data.

One explanation for this apparent paradox is to recognise the nonlinearity of the expansion of democratic rights. While extensions of political participation may induce faster growth or retard economic development, in either case, this occurs only up to a certain point (Barro, 1996). This nonlinearity can also be used to rationalise the potential tension - as highlighted in the theoretical literature - between a democratic regime as a positive force for economic development versus the negative effects of democracies. Minier (2007) has recently studied nonlinearities in the effects of institutions (generally defined) on growth. Future work would extend this to allow for nonlinear democratic development as well. Indeed, it may well be the case that, in a sufficiently diverse sample, these two contrary effects cancel each other out, resulting in a net zero impact from democracy. Although we are unable to draw strong conclusions regarding the desirability of democracy or autocracy in fostering development, to assert that the political regime does not matter seems, to us, an unwarranted, extreme conclusion. More generally, additional research is needed to understand the theoretical drivers behind how political-economic and political institutions affect growth.

\footnotetext{
${ }^{14}$ Lee Kwan Yew, the architect of Singapore's rapid rise from a riot-ridden, malaria-infested tropical island to one of the world's richest nations (in per capita terms), has even argued that 'what a country needs to develop is discipline more than democracy. The exuberance of democracy leads to indiscipline and disorderly conduct which are inimical to development' (Lee, 2000, p. 304).
} 
Nonetheless, as far as enhancing economic performance is concerned, developing countries may be far better served by concentrating on improving the quality of political-economic institutions that exert a more direct, first-order influence on the functioning of market processes - such as the rule of law (La Porta et al., 1998) and the enforcement of property rights (Djankov et al., 2002) - rather than expanding their energies on building participatory political institutions. It would be unwise to claim, therefore, that the policy implication of this study is that promoting democratic development is irrelevant. Doing so would disregard the tremendous value afforded -in terms of individual freedom and political representation-by democracy per se. It seems unwise to substitute such intangibles in favour of growth, at any cost.

\section{ACKNOWLEDGEMENTS}

We are indebted to many helpful conversations and comments by Jonathon Adams-Kane, Joshua Aizenman, Kay Pommerenke and an anonymous referee (who suggested the System GMM approach). Thanks are also due to Dani Rodrik for kindly providing data. Financial support for this project was in part from funding from the Faculty Development Committee, Centre College (Decker and Lim), and the Graduate Division, University of California, Santa Cruz (Lim). The findings, interpretations, and conclusions expressed in this article are entirely those of the authors. They do not necessairly represent the views of The World Bank, its Executive Directors, or the countries they represent. All errors and omissions remain firmly in our domain.

\section{REFERENCES}

Acemoglu KD, Johnson S. 2005. Unbundling institutions. Journal of Political Economy 113(5): 949-995.

Acemoglu KD, Johnson S, Robinson JA. 2001. The colonial origins of comparative development: an empirical investigation. The American Economic Review 91(5): 1369-1401.

Acemoglu KD, Robinson JA. 2000. Why did the west extend the franchise? Democracy, inequality, and growth in historical perspective. Quarterly Journal of Economics 115(4): 1167-1199.

Alesina A, Rodrik D. 1994. Distributive politics and economic growth. Quarterly Journal of Economics 109(2): 2.

Arellano M, Bond SR. 1991. Some tests of specification for panel data: Monte Carlo evidence and an application to employment equations. Review of Economic Studies 58(2): 277-297.

Arellano M, Bover O. 1995. Another look at the instrumental variable estimation of errorcomponents models. Journal of Econometrics 68(1): 29-51.

Barro RJ. 1996. Democracy and growth. Journal of Economic Growth 1(1): 1-27.

Barro RJ. 1999. Determinants of democracy. Journal of Political Economy 107 (6/2 (Supplement)): S158-S183.

Barro RJ, Lee JW. 1996. International measures of schooling years and schooling quality. American Economic Review 86(2): 218-223.

Beck T, Clarke GR, Groff A, Keefer PE, Walsh PP. 2001. New tools in comparative political economy: the database of political institutions. World Bank Economic Review 15(1): 165-176.

Bhagwati JN. 2002. Democracy and development: cruel dilemma or symbiotic relationship? Review of Development Economics 6(2): 151-162. 
Blundell R, Bond SR. 1998. Initial conditions and moment restrictions in dynamic panel data models. Journal of Econometrics 87(1): 115-143.

Bond SR. 2002. Dynamic panel data models: a guide to micro data methods and practice. Portuguese Economic Journal 1(2): 141-162.

Brunetti A. 1997. Political variables in cross-country growth analysis. Journal of Economic Surveys 11(2): 163-190.

Bueno de Mesquita B, Morrow JD, Siverson RM, Smith A. 1999. An institutional explanation of the democratic peace. American Political Science Review 93(4): 791-807.

Butkiewicz JL, Yanikkaya H. 2006. Institutional quality and economic growth: maintenance of the rule of law or democratic institutions, or both? Economic Modelling 23(4): 648-661.

Carstensen Kai, Gundlach Erich. 2006. The primacy of institutions reconsidered: direct income effects of malaria prevalence. World Bank Economic Review 20(3): 309-339.

Diamond J. 1997. Guns, Germs and Steel: The Fates of Human Societies. W.W. Norton: New York, NY.

Djankov S, La Porta R, Lopez-de Silanes F, Shleifer A. 2002. The regulation of entry. Quarterly Journal of Economics 117(1): 1-37.

Frankel JA, Romer D. 1999. Does trade cause growth? American Economic Review 89(3): 379-399.

Freedom House. 2007. Freedom in the World: The Annual Survey of Political Rights and Civil Liberties. Rowman \& Littlefield: Lanham, MD.

Friedman M. 1962. Capitalism and Freedom. University of Chicago Press: Chicago, IL.

Glaeser EL, La Porta R, López-de Silanes F, Shleifer A., 2004. Do institutions cause growth? Journal of Economic Growth 9(3): 271-303.

Gradstein M. 2007. Inequality, democracy and the protection of property rights. Economic Journal 117(516): 252-269.

Hall RE, Jones CI. 1999. Why do some countries produce so much more output per worker than others? Quarterly Journal of Economics 114(1): 83-116.

Hayek FA. 1944. The Road to Serfdom. Routledge \& Kegan Paul: London, England.

Henisz WJ. 2000. The institutional environment for economic growth. Economics \& Politics 12(1): $1-32$.

Heston A, Summers R, Aten B. 2006. Penn World Table (6.2 edn). Center for International Comparisons of Production, Income and Prices: Philadelphia, PA.

Kaufmann D, Kraay A, Mastruzzi M. 2007. Governance Matters: Governance Indicators for 1996-2006 (VI edn). The World Bank: Washington, DC.

Knack S, Keefer P. 1995. Institutions and economic performance: cross-country tests using alternative institutional measures. Economics \& Politics 7(3): 207-227.

La Porta R, Lopez-de Silanes F, Shleifer A, Vishny RW. 1998. Law and finance. Journal of Political Economy 106(6): 1113-1155.

Lee KY. 2000. From Third World to First: The Singapore Story: 1965-2000. Times Publishers: Singapore.

Mankiw NG, Romer D, Weil DN. 1992. A contribution to the empirics of economic growth. Quarterly Journal of Economics 107(2): 407-437.

Marshall MG, Jaggers K. 2005. Polity IV Project: Political Regime Characteristics and Transitions, 1800-2004 (IV edn). Center for International Development and Conflict Management: College Park, MD.

Minier JA. 2007. Institutions and parameter heterogeneity. Journal of Macroeconomics 29(3): 3.

Mobarak AM. 2005. Democracy, volatility, and economic development. Review of Economics and Statistics 87(2): 348-361. 
Parente SL, Rui Z. 2006. Slow development and special interests. International Economic Review 47(3): 991-1021.

Persson T, Tabellini G. 1994. Is inequality harmful for growth? Theory and evidence. American Economic Review 84(3): 600-621.

Persson T, Tabellini G. 2006. Democracy and development: the devil in the details. American Economic Review 96(2): 319-324.

Persson T, Tabellini G. 2007. The growth effect of democracy: is it heterogenous and how can it be estimated? Working Paper 13150, NBER.

Political Risk Services. 2003. International Country Risk Guide. The PRS Group: East Syracuse, NY.

Przeworski A, Limongi F. 1993. Political regimes and economic growth. Journal of Economic Perspectives 7(3): 51-69.

Rivera-Batiz FL. 2002. Democracy, governance, and economic growth: theory and evidence. Review of Development Economics 6(2): 225-247.

Rivera-Batiz FL, Rivera-Batiz LA. 2002. Democracy, participation, and economic development: an introduction. Review of Development Economics 6(2): 135-150.

Rodrik D, Subramanian A, Trebbi F. 2004. Institutions rule: the primacy of institutions over geography and integration in economic development. Journal of Economic Growth 9(2): 131-165.

Rodrik D, Wacziarg R. 2005. Do democratic transitions produce bad economic outcomes? American Economic Review 95(2): 50-55.

Sachs JD. 2001. Tropical underdevelopment. Working Paper 8119, NBER.

Sachs JD. 2003. Institutions don't rule: direct effects of geography on per capita income. Working Paper 9490, NBER.

Sachs JD, Warner AM. 1995. Economic reform and the process of global integration. Brookings Papers on Economic Activity 1: 1-118.

Usher D. 1981. The Economic Prerequisite to Democracy. Columbia University Press: New York, NY.

Vega-Gordillo M, Álvarez Arce JL. 2003. Economic growth and freedom: a causality study. Cato Journal 23(2): 199-215.

Verdier TA, Saint-Paul G. 1993. Education, democracy and growth. Journal of Development Economics 42(2): 399-407.

Windmeijer F. 2005. A finite sample correction for the variance of linear efficient two-step GMM estimators. Journal of Econometrics 126(1): 25-51.

\section{APPENDIX}

This appendix discusses in greater detail various variables employed in the regression analyses.

Ethnolinguistic fractionalisation involved the use of two variables that capture the fraction of the population speaking English, and the fraction of the population speaking other European languages.

The measure of institutions using Kaufmann et al. (2007) included the following variables: voice and accountability, political stability, government effectiveness, regulatory quality, rule of law and control of corruption. The estimates were assumed to be drawn from a normal distribution centred on zero with support $[-1,1]$. We dropped the first of these-which seems to be a better proxy for democratic representation-and equally 
weigh the remaining of these five dimensions in the composite score:

$$
\mathrm{INS}_{i}=0.2 \mathrm{Stab}_{i}+0.2 \operatorname{Gov}_{i}+0.2 \operatorname{Reg}_{i}+0.2 \mathrm{Law}_{i}+0.2 \mathrm{Corrupt}_{i}
$$

The composite measure using Political Risk Services (2003) included very similar variables: bureaucracy quality, corruption, government stability and rule of law. These were scored from $0-12$ for government stability, $0-6$ for corruption and rule of law and 0-4 for bureaucracy quality. The composite was thus the log transform

$$
\mathrm{INS}_{i t}=\ln \left(3 \times \text { Bureau }_{i t}+2 \times \text { Corrupt }_{i t}+\mathrm{Gov}_{i t}+2 \times \mathrm{Law}_{i t}\right)
$$

The alternative democracy variable provided by Freedom House (2007) is a composite of two main variables: political rights and civil liberties. The former comprise electoral process, political pluralism and government functioning, while the latter comprise freedom of expression, associational rights, rule of law and personal autonomy. Each variable is scored from 1 to 7 and weighted equally according to

$\mathrm{DEM}_{i t}=0.5$ Rights $_{i t}+0.5 \mathrm{Lib}_{i t}$ 